\title{
PRODUKCJA W SPADKOWEJ FAZIE CYKLU KONIUNKTURALNEGO W POLSCE
}

\section{WSTEP}

Faza spadkowa, która we współczesnych gospodarkach przybiera często postać tylko spowolnienia wzrostu gospodarczego, jest ostatnią fazą cyklu koniunkturalnego. Przynosi ona ludziom i przedsiębiorstwom wiele problemów. Spadek produkcji w wielu branżach prowadzi przede wszystkim do wzrostu bezrobocia i spadku dochodów. Ważne są również straty w sferze psychicznej. Panująca atmosfera zawodu i przegranej wpływa negatywnie na decyzje przedsiębiorców. Jednak nie wszyscy odczuwają skutki dekoniunktury w taki sam sposób. Według szkoły austriackiej czasowa struktura produkcji dostosowuje się do czasowej struktury konsumpcji. Oznacza to, że zmiany produkcji dotykaja poszczególnych branży w różnym stopniu.

W teorii ekonomii istnieje wiele teorii cyklu koniunkturalnego, między innymi psychologiczne, technologiczne, pieniężne, popytowe ${ }^{1}$. Jedną z teorii pieniężnych jest teoria szkoły austriackiej. W opracowaniu przyjęto interpretację cyklu sformułowaną przez tę szkołę. Kryzys gospodarczy powstały w 2008 r., który szczególnie dotknął Stany Zjednoczone oraz kraje strefy euro, poprzedzony był ekspansywną polityką pieniężną. Dlatego teoria szkoły austriackiej, która skupia się na polityce banku centralnego, jest interesująca propozycją wyjaśniania przyczyn i opisu przebiegu wahań koniunkturalnych, a szczególnie fazy spadkowej.

Niniejsze opracowanie ma charakter teoretyczno-empiryczny, ale jego najważniejszą częścią jest część empiryczna, a głównym celem - weryfikacja dwóch hipotez, które sa podstawowymi elementami teorii cyklu koniunkturalnego szkoły austriackiej. Pierwsza hipoteza mówi, że restrykcyjna polityka pieniężna powoduje skracanie struktury produkcji, czyli zmniejszanie czasu wytwarzania dóbr konsumpcyjnych; druga - dotyczy zmian produkcji w poszczególnych branżach. Mówi ona, że podwyżki stóp procentowych prowadzą do powstania względnych różnic w spadku produkcji branż wytwarzających dobra w różnych odległościach od konsumenta.

Możliwość weryfikacji tak postawionych hipotez za pomocą modeli ekonometrycznych - które obecnie są często wykorzystywane w badaniach zmian

\footnotetext{
${ }^{1}$ Zob. R. Barczyk, Gtówne teorie wspótczesnych wahań koniunkturalnych, Wydawnictwo Akademii Ekonomicznej w Poznaniu, Poznań 1997; J. A. Estey, Cykle koniunkturalne, PWG, Warszawa 1959; M. Lubiński, Analiza koniunktury i badanie rynków, Elipsa, Warszawa 2004.
} 
kategorii makroekonomicznych - jest bardzo ograniczona. Takie modele stosuja ekonomiści szkół głównego nurtu, gdyż posługują się kategoriami zagregowanymi. Te zaś są sprzeczne ze sposobem analizy szkoły austriackiej. Dlatego w opracowaniu zastosowano metodę wnioskowania dedukcyjnego oraz metodę porównawczą.

Podstawowy okres badawczy to lata 2004-2009. Z lat 2002-2009, które obejmuja cały cykl Juglara oraz dwa cykle Kitchina ${ }^{2}$, wyszczególniono dwie spadkowe fazy cyklu koniunkturalnego w polskiej gospodarce. Pierwsza, krótka i płytka, występowała na przełomie lat 2004 i 2005. Natomiast druga, dłuższa i o wiele głębsza, w latach 2008-2009. Można ją traktować jako ostatnią fazę cyklu Juglara.

Wszystkie dane wykorzystane $\mathrm{w}$ opracowaniu są wielkościami na koniec poszczególnych kwartałów. Pochodzą z publikacji i stron internetowych Głównego Urzędu Statystycznego oraz Narodowego Banku Polskiego.

\section{PRODUKCJA W FAZIE KRYZYSU W TEORII SZKOŁY AUSTRIACKIEJ}

Ekspansywna polityka banku centralnego, która obecnie opiera się na pieniądzu fiducjarnym, w klasycznym ujęciu cyklu, wywołuje, ożywienie i boom w gospodarce. Natomiast w ujęciu współczesnym - fazę wysokiej dynamiki wzrostu $^{3}$. Obniżona stopa procentowa zachęca przedsiębiorców do zwiększania produkcji i zatrudnienia, które finansowane są pieniądzem wykreowanym przez system bankowy ${ }^{4}$. Proces ten zapoczątkowuje rachunki i decyzje podmiotów dotyczące czasowej struktury produkcji w oderwaniu od czasowej struktury konsumpcji. ,,Jest to [...] typowy przykład nakłaniania przedsiębiorców do masowego popełniania błędu w kalkulacji ekonomicznej bądź w oszacowaniu wyników różnych możliwych kierunków działania. Ten błąd rachunku ekonomicznego wynika z faktu, że jeden z podstawowych wskaźników, do których odwołują się przedsiębiorcy przed przystąpieniem do działania, mianowicie stopa procentowa [...] staje się przejściowo przedmiotem manipulacji banków i zostaje przez nie sztucznie obniżony" ${ }^{5}$. Masowe błędy przedsiębiorców nie mogą trwać w nieskończoność. Muszą zostać z gospodarki wyeliminowane. Dlatego faza spadkowa (kryzys), która współcześnie jest często okresem relatywnie niskiej dynamiki wzrostu produktu krajowego ${ }^{6}$, jest nieunikniona konsekwencją pieniężnego pobudzania działalności podmiotów gospodarczych ${ }^{7}$.

${ }^{2}$ Zob. K. Piech, Rodzaje cykli gospodarczych, „Polityka Gospodarcza” 2001-2002, nr 5-6.

${ }^{3}$ I. Mintz, Dating American Growth Cycle, w: V. Zarnowitz (red.), The Business Cycle Today, NBER, t. 1, New York 1972.

${ }^{4}$ W. L. Anderson, Say's Law and the Austrian Theory of the Business Cycle, „Quarterly Journal of Austrian Economics" 12, 2009, nr 2.

${ }^{5} \mathrm{~J}$. Huerta de Soto, Pieniadz, kredyt bankowy i cykle koniunkturalne, Instytut Ludwika von Misesa, Warszawa 2009, s. 265-266.

${ }^{6}$ I. Mintz, op. cit.

${ }^{7}$ Por. M. Friedman, A. Schwartz, A Monetary History of the United States 1867-1960, Princeton University Press, Princeton 1963; M. N. Rothbard, Wielki Kryzys w Ameryce, Instytut Ludwika von Misesa, Warszawa 2010; A. Sławiński, Przyczyny globalnego kryzysu bankowego, w: J. Osiński, 
Powstaje podstawowe pytanie: dlaczego wywołany takim sposobem silny wzrost gospodarczy załamuje się i dochodzi do kryzysu? Odpowiedź na nie wymaga przeanalizowania czynników, które decydują o zmianach zachowań przedsiębiorców i konsumentów.

Czynnikiem rozpoczynającym, jeszcze w okresie boomu, stopniowe formowanie się kryzysu jest wzrost cen dóbr konsumpcyjnych. Ceny tych dóbr zaczynają wzrastać w tempie szybszym niż ceny pierwotnych czynników produkcji, czyli pracy i ziemi, oraz ceny produktów wytwarzanych na etapach dalszych od konsumpcji ${ }^{8}$. Wynika to z kilku przyczyn. Pierwszą przyczyną jest wzrost dochodów właścicieli pierwotnych czynników produkcji. Rosnące dochody sa wynikiem wzrostu ilości wykorzystywanych czynników oraz podnoszenia się ich cen. Drugą przyczyną jest spowolnienie produkcji dóbr konsumpcyjnych. Wydłużanie się struktury produkcji po obniżeniu stóp procentowych sprawia, że czynniki produkcji przesuwają się z etapów bliższych konsumentowi do etapów bardziej od niego oddalonych. Co więcej, wydłużenie oznacza zwiększenie czasu wytwarzania, a więc późniejsze dostarczenie dóbr konsumpcyjnych na rynek. Trzecia przyczyną są wydatki, które wynikaja z zysków osiagganych przez przedsiębiorców. Zyski te sa wysokie, ale jednak tylko rachunkowe. Przedsiębiorcy obliczaja je, korzystając z historycznych danych o kosztach. Bogacenie się zwiększa chęć do korzystania z konsumpcji ${ }^{9}$.

Szybszy wzrost cen dóbr finalnych w porównaniu z wzrostem cen dóbr pośrednich oznacza wzrastająca rentowność przedsiębiorstw wytwarzających bliżej konsumenta w porównaniu z tymi z dalszych etapów. Dzieje się tak na skutek podobnej dynamiki kosztów produkcji na każdym etapie wytworzenia. Proces ten zmusza wielu przedsiębiorców do przemyślenia swoich decyzji inwestycyjnych - rozważaja, czy nie przenieść zasobów do bliższych etapów. Powoli zapoczątkowuje się proces przesuwania kapitałów do realizacji projektów gospodarczych, które mają krótszy okres produkcji dóbr niższego rzędu. Oznacza to, że dochodzi do zmiany czasowej struktury produkcji. Czynniki produkcji z dalszych etapów zaczynają wracać do niższych. Powoli kształtuje się kryzys, który ma za zadanie przywrócić poprzednią strukturę wytwarzania dóbr konsumpcyjnych. Tę strukturę, która istniała przed obniżeniem nominalnej stopy procentowej przez bank centralny. Wynikała ona $\mathrm{z}$ dobrowolnych decyzji dotyczących podziału dochodu na konsumpcję i oszczędności. Podział ten tworzył w gospodarce informację, która dopasowywała do siebie czasowe struktury produkcji i konsumpcji. „Nie ma już nic, co by dowodziło, że adresaci dochodów zwiększą odsetek oszczędności. Wynika więc z tego, że w miarę jak nowy pieniądz staje się dochodem, musimy spodziewać się wzmocnienia popytu, nie na dobra kapitałowe, lecz na dobra dochodowe. Stary stosunek popytu na dobra dochodowe i popytu na dobra kapitałowe musi być ponownie ustalony" ${ }^{10}$.

S. Sztaba (red.), Nauki spoteczne wobec kryzysu na rynkach finansowych, SGH, Warszawa 2009; A. Wojtyna (red.), Kryzys finansowy i jego skutki dla krajów na średnim poziomie rozwoju, PWE, Warszawa 2011.

${ }^{8}$ Zob. F. A. von Hayek, Prices and Production, New York 1967.

9 W. Block, K. M. Garschina, Hayek, Business Cycles and Fractional Reserve Banking: Continuing the De-Homogenization Process, , Review of Austrian Economics” 9, 1996, nr 1.

${ }^{10}$ L. Robbins, The Great Depression, Macmillan, London 1934, s. 38. 


\section{Wykres 1}

Zmiana struktury produkcji w fazie spadkowej

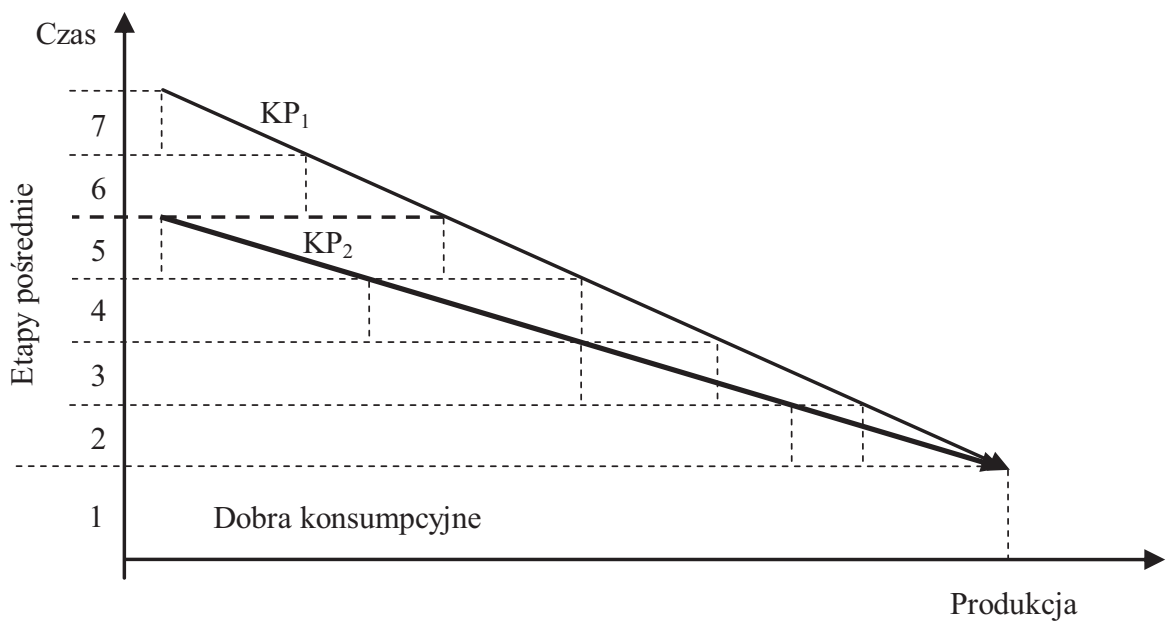

Źródło: opracowanie własne na podstawie M. Skousen, Struktura produkcji. Gietda, kapitat, konsumpcja, Fijorr Publishing, Warszawa 2011.

W celu prezentacji zachowania się produkcji w fazie dekoniunktury według teorii ekonomii szkoły austriackiej, tak samo jak w opracowaniu dotyczacym wzrostowej fazy cyklu koniunkturalnego, wykorzystano propozycje graficzna M. Skousena (wykres 1) ${ }^{11}$. W okresie kryzysu w strukturze i wielkości produkcji zachodzą zmiany odwrotne do tych, które występowały w fazie lepszej koniunktury. Krzywa produkcji $\mathrm{KP}_{1}$, która mierzy roczną wartość produkcji na wszystkich jej etapach, począwszy od surowców aż po finalne dobra konsumpcyjne, zostaje spłaszczona i obniżona, przyjmując postać krzywej $\mathrm{KP}_{2}$. Początkowa struktura produkcji składa się z siedmiu etapów, których numeracja, zgodnie z ujęciem C. Mengera, zwiększa się wraz z odległością od ostatecznej konsumpcji. Mniejszy kąt nachylenia krzywej $\mathrm{KP}_{2}$ oznacza, że w gospodarce zostały zlikwidowane najdalsze etapy wytwarzania dóbr konsumpcyjnych. Jak w okresie wysokiego wzrostu występowało wydłużanie procesu wytwórczego, tak teraz dochodzi do skracania (spłycania) struktury produkcji. Przedsiębiorcy zmniejszają inwestycje w badania i rozwój, opracowywanie i wdrażanie nowych technologii oraz skracają czas budowy obiektów gospodarczych. Dochodzi także do spadku zapasów surowców i półproduktów wykorzystywanych w dalszej produkcji. Graficznie na wykresie 1 skracanie struktury produkcji przedstawione jest to jako eliminacja $\mathrm{z}$ dotychczasowej struktury wytwarzania, która składała się z etapów 1-7, dwóch etapów oznaczonych numerami 7 i 6 . Sa to etapy najbardziej oddalone od finalnej

${ }^{11}$ A. Jędruchniewicz, Produkcja we wzrostowej fazie cyklu koniunkturalnego $w$ Polsce, „Gospodarka Narodowa" 2012, nr 10. 
konsumpcji. Krótsza struktura produkcji prowadzi do mniej kapitałochłonnego i prostszego technicznie procesu wytwarzania. Skutkuje także tym, że czas produkcji dóbr konsumpcyjnych jest krótszy. W długim okresie efektem tego procesu jest mniejsza ilość oraz gorsza jakość techniczna dóbr finalnych.

Wraz ze skracaniem struktury produkcji w gospodarce dochodzi również do jej zwężania. Graficznie obrazuje to przesunięcie krzywej $\mathrm{KP}_{1} \mathrm{w}$ lewo na wykresie $1 . \mathrm{Z}$ analizy nowej krzywej $\mathrm{KP}_{2}$ wynika, że zmniejszenie inwestycji powoduje spadek produkcji dóbr na większości etapów, które pozostały w nowej strukturze produkcji. Dla szkoły austriackiej produkcja nie jest zagregowana, inaczej niż dla szkół głównego nurtu ${ }^{12}$. Dlatego występujący spadek produkcji nie jest taki sam we wszystkich etapach tworzenia dóbr konsumpcji (wykres 2). Dla Austriaków ważne są przede wszystkim zmiany względne badanych kategorii. Tempo spadku jest proporcjonalne do stopnia oddalenia dobra od konsumpcji oraz jego trwałości. Odwrotnie w stosunku do fazy wzrostowej w okresie kryzysu największe spadki występują w produkcji dóbr wyższego rzędu (dobra pośrednie) najdalszych od konsumpcji (np. stali) oraz o najdłuższym okresie używania (np. budynków). Natomiast mniejsze spadki pojawiają się na etapach bliższych konsumpcji (np. materiał na ubrania) oraz o krótszym okresie użytkowania dobra (np. meble). Na wszystkich etapach pośrednich spadki produkcji występuja najczęściej, gdy w gospodarce istnieje silna i długa recesja, a więc produkt krajowy znacząco maleje w dłuższym okresie. Jednak we współczesnej fazie niskiego wzrostu produkcja na etapach znajdujących się najbliżej konsumenta oraz nietrwałych dóbr konsumpcyjnych charakteryzuje się dodatnią dynamiką. Przyczynami tego są przesunięcia, w miarę możliwości, dóbr kapitałowych z dalszych etapów wytwarzania do tych bliżej konsumenta, wzrost kredytów konsumpcyjnych oraz polityka fiskalna nakierowana na wzrost dochodów i spożycia ludności. Generalnie jednak w okresie dekoniunktury produkcja dóbr konsumpcyjnych względnie wzrasta $\mathrm{w}$ stosunku do produkcji innych branż $\dot{1}^{13}$.

Przemieszczanie się zasobów do niższych etapów wytwórczych, związane $\mathrm{z}$ wyższą marżą zysku, sprawia, że w przedsiębiorstwach wytwarzających na etapach odległych od ostatecznej konsumpcji pojawiaja się straty księgowe. „Zestawienie tych strat ze względnymi zyskami osiaganymi na etapach najbliższych konsumpcji wskazuje ponad wszelką wątpliwość, że przedsiębiorcy popełnili poważne błędy i trzeba je szybko skorygować, wstrzymując, a następnie likwidując nierozważnie zainicjowane projekty inwestycyjne $[. . .]^{\prime 14}$. Przedsiębiorcy uświadamiają sobie ogrom popełnianych błędów, które wynikają z braku międzyokresowej koordynacji związanej z dobrowolnymi oszczędnościami i inwestycjami. Konieczne staje się przywrócenie poprzedniej czasowej struktury produkcji poprzez likwidacje nierentownych inwestycji i przeniesienie kapitału bliżej konsumenta. W tym momencie dochodzi do załamania produkcji w wielu branżach, gdyż większość przedsiębiorców, którzy walczyli o dokończenie swoich inwestycji poddaje się. Rozpoczyna się faza spadkowa.

${ }^{12}$ Zob. B. Snowdon, H. Vane, P. Wynarczyk, Wspótczesne nurty teorii makroekonomii, WN PWN, Warszawa 1998; A. Wojtyna, Ewolucja keynesizmu a główny nurt ekonomii, PWN, Warszawa 2000.

${ }^{13}$ W. Block, K. M. Garschina, op. cit.

14 J. Huerta de Soto, op. cit., s. 284. 


\section{Wykres 2}

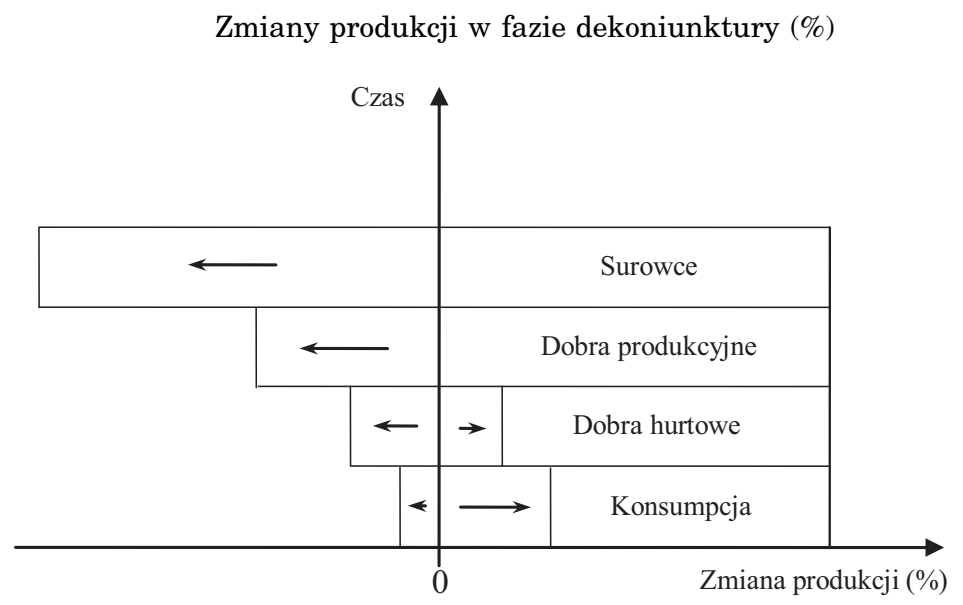

Źródło: opracowanie własne.

Zachodzące procesy wzmacniane są zmianami w kosztach produkcji, które dotycza płac realnych. Obserwowany jest tak zwany efekt Ricardo. Nosi on również nazwę ,sytuacji Hayeka" ${ }^{15}$. Szybciej rosnące ceny konsumpcyjne niż płace nominalne powodują spadek płac realnych. Dla firm praca ludzi staje się względnie tańsza niż zakup i wykorzystywanie dóbr kapitałowych. Zgodnie z efektem substytucji czynników produkcji dążą więc one do zastępowania maszyn i urządzeń technicznych, tam gdzie to jest możliwe, pracownikami ${ }^{16}$. Taka zamiana prowadzi do pogłębienia spadku popytu na dobra kapitałowe, co prowadzi do zaprzestania produkcji przez część firm z etapów najbardziej oddalonych od konsumpcji. Jednak wiele firm walczy o dokończenie rozpoczętych inwestycji. Dlatego zwracają się do banków o dodatkowe kredyty inwestycyjne, aby zapewnić finansowanie tych projektów. Rosnący popyt na kredyty oraz coraz wyższa inflacja sprawiaja, że tuż przed załamaniem się produkcji dóbr wyższego rzędu wzrasta stopa procentowa. Rośnie ona do poziomu wyższego, niż wynosiła przez obniżką banku centralnego ${ }^{17}$. Natomiast maleje podaż pieniądza lub jej dynamika. Główną tego przyczyną jest ograniczenie ekspansji kredytowej banków komercyjnych, obawiających się trudności w spłacie kredytów.

Kryzys, który jest skutkiem ekspansji pieniądza fiducjarnego, w ostateczności prowadzi do ubożenia społeczeństwa. W okresie gorszej koniunktury kumulują się niepożądane zjawiska. Przede wszystkim dochodzi do bankructw przedsiębiorstw, które zainwestowały zbyt optymistycznie. Pociąga to za sobą

15 J. Godłów-Legiędź, Doktryna społeczno-ekonomiczna Friedricha von Hayeka, PWN, Warszawa 1992, s. $169-174$.

${ }^{16}$ F. A. von Hayek, „Profits, Interest and Investment” and Other Essays on the Theory of Industrial Fluctuations, Clifton 1975, s. 9-28.

${ }^{17}$ L. von Mises, Ludzkie dziatanie. Traktat o ekonomii, Instytut Ludwika von Misesa, Warszawa 2007, s. $479-483$. 
spadek poziomu kapitału. Nie wraca on do poziomu sprzed początku cyklu ${ }^{18}$. Główna przyczyna jest istnienie wielu specyficznych dóbr kapitałowych, których nie można przenieść do innego rodzaju produkcji ${ }^{19}$. Te dobra zostana w pełni zmarnowane. Szczególnie dotkliwy dla ludzi jest znaczący wzrost bezrobocia. Tak jak zmiana produkcji, także i ono dotyczy przede wszystkim etapów znajdujących się najdalej od konsumenta. Oprócz zmian materialnych istotne są niekorzystne zmiany w psychice ludzi. „Boom prowadzi do zubożenia, ale jeszcze poważniejsze szkody wyrządza w sferze moralnej. Wywołuje przygnębienie i zniechęcenie. Im większy optymizm panował w okresie iluzorycznej prosperity, jaką przysnuł boom, tym większe jest uczucie zawodu i frustracji po jego zakończeniu" ${ }^{20}$.

Końcowym etapem fazy spadkowej jest depresja albo inaczej okres zastoju. Ma ona ważną rolę do spełnienia. Podstawowym jej zadaniem jest przywrócenie odpowiedniej struktury wytwarzania w gospodarce. W tym czasie przedsiębiorstwa na nowo określaja poziom inwestycji, finansowanych dobrowolnymi oszczędnościami, który umożliwi dopasowanie czasowej struktury produkcji do dobrowolnego poziomu konsumpcji w społeczeństwie. Współcześnie okres depresji jest mocno zniekształcony antycykliczną polityką państwa ${ }^{21}$.

\section{CYKL KONIUNKTURALNY I POLITYKA MONETARNA W POLSCE}

Cykl ogólnie definiowany jest jako „krótkookresowe odchylenia produkcji od jej trendu"22. Obecnie często występuje tak zwany cykl wzrostu, na który składają się dwie fazy: relatywnie wysokiej oraz niskiej stopy wzrostu ${ }^{23}$. Współczesna definicja mówi, że cykl ,,[...] jest to sekwencja następujących w czasie faz pomyślnej i niepomyślnej koniunktury, przy czym następstwo to jest względnie regularne" ${ }^{24}$. Pierwsza faza utożsamiana jest $\mathrm{z}$ okresem wzrostowym, a druga - z okresem spadkowym cyklu.

Do wyodrębnienia spadkowych faz cyklu w Polsce zostanie wykorzystana główna zagregowana kategoria w gospodarce, czyli produkt krajowy brutto. Wykorzystanie zmian PKB pozwala określić przedziały czasowe trwania poszczególnych faz na kilka sposobów. Pierwszym sposobem jest wykorzystanie trendu. „Cykle wzrostu są określane w tym przypadku bądź jako odchylenia

\footnotetext{
18 M. Skousen, op. cit., s. 350-352.

19 Zob. G. L. S. Shackle, Some Notes on Monetary Theories of the Trade Cycle, „Review of Economic Studies" 1, 1933, nr 1.

${ }^{20}$ L. von Mises, op. cit., s. 488.

${ }^{21}$ Zob. R. Barczyk, Teoria i praktyka polityki antycyklicznej, Wydawnictwo Akademii Ekonomicznej w Poznaniu, Poznań 2004.

${ }^{22}$ D. Begg, S. Fischer, R. Dornbusch, Makroekonomia, PWE, Warszawa 2003, s. 339.

${ }^{23}$ Zob. R. Barczyk, M. Lubiński, Dylematy stabilizowania koniunktury, Wydawnictwo Uniwersytetu Ekonomicznego w Poznaniu, Poznań 2009; M. Drozdowicz-Bieć, Cykle i wskaźniki koniunktury, Poltext, Warszawa 2012.

${ }^{24}$ R. Barczyk, et al., Nowe oblicza cyklu koniunkturalnego, PWE, Warszawa 2006, s. 143.
} 
wartości empirycznych PKB od oszacowanych wartości trendu, bądź też jako [...] zmiany stóp wzrostu realnego produktu krajowego brutto"25. Drugim sposobem, proponowanym przez ekonomistów ze szkoły monetarnej, jest użycie średniego tempa wzrostu $\mathrm{PKB}^{26}$. Natomiast trzecim sposobem jest wykorzystanie filtrów: Hodricka-Prescotta, Christiano-Fitzgeralda, spektralnego Christiano-Fitzgeralda.

\section{Wykres 3}

Roczne zmiany realnego PKB w Polsce (\%) oraz jego trendy

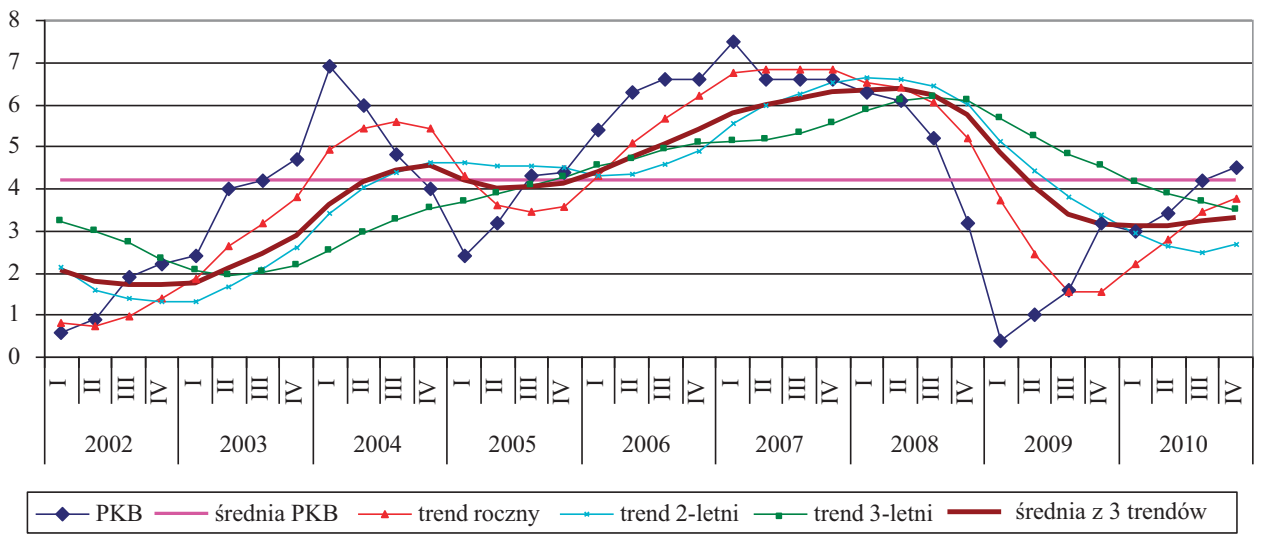

Źródło: Biuletyn Statystyczny z lat 2003-2011, GUS, Warszawa oraz obliczenia własne.

Stosując metodę porównania rocznych zmian PKB do średniej z dziewięcioletniego okresu $(4,2 \%)$ w latach 2002-2010, można wyznaczyć dwie pełne spadkowe fazy cyklu w gospodarce polskiej (wykres 3). Metoda ta jest praktyczna. Jednak podstawowym problemem przy jej wykorzystaniu są opóźnione sygnały zmiany fazy cyklu. Dlatego najczęściej w badaniach wahań cyklicznych wykorzystywany jest trend zmian PKB. Taka metoda również nie jest pozbawiana wad. Główna to problem związany z wyborem trendu. Wykres 3 zawiera trendy wyznaczone jako średnie kroczące oparte na danych kwartalnych. Za podstawę określenia faz cyklu w Polsce przyjęto średnią obliczona z trzech trendów: rocznego, 2- oraz 3-letniego. Trend roczny prowadziłby do zbyt wczesnego pojawiania się sygnałów o zmianie fazy, a 3-letni - informowałby ze zbyt dużym opóźnieniem. Natomiast niekiedy wartości trendu 2-letniego sa bliskie wartościom trendu rocznego lub 3-letniego. Na podstawie średniej z trzech trendów w latach 2002-2010 zostały wyznaczone następujące okresy spadkowe cyklu w Polsce: IV kwartał 2004 - II kwartał 2005 oraz III kwartał

\footnotetext{
25 R. Barczyk, M. Lubiński, op. cit., s. 15.

${ }^{26}$ M. Friedman, A. J. Schwartz, Money and Business Cycles, „Review of Economics and Statistics" 45, 1963, nr 1, s. 32-78.
} 
2008 - III kwartał 2009. Początek drugiej fazy został arbitralnie opóźniony ze względu na wysoką i podobną do poprzedzających kwartałów dynamikę PKB. Zbliżone okresy zostały wyznaczone przez innych ekonomistów ${ }^{27}$.

W Strategii polityki pieniężnej po $2003 \mathrm{r}$. na nowo skwantyfikowano cel główny Narodowego Banku Polskiego, ogólnie sformułowany w ustawie z 29 sierpnia 1997 r. o Narodowym Banku Polskim, i zapisano go jako: ,[...] ustabilizowanie stopy inflacji na poziomie 2,5\% z dopuszczalnym przedziałem wahań +/- 1 punkt procentowy" ${ }^{28}$. Rok 2004 był więc pierwszym rokiem $\mathrm{z}$ nowo określonym poziomem celu inflacyjnego. Był też pierwszym rokiem w analizowanym okresie 2002-2010, w którym bank centralny dokonał pierwszej podwyżki stóp procentowych (1 lipca 2004 r.). W lipcu i sierpniu zostały dokonane jeszcze dwie podwyżki stóp NBP. Główną przyczyną tych podwyżek była presja inflacyjna. Inflacja mierzona CPI już w II kwartale przekraczała cel inflacyjny. „Podwyżki stóp procentowych miały ograniczyć ryzyko pojawienia się wtórnych skutków wzrostu inflacji związanego z przystąpieniem Polski do UE oraz wzrostem cen ropy naftowej i innych surowców na rynkach światowych. [...] Taka sytuacja rodziłaby ryzyko wzrostu presji płacowej i - w konsekwencji - utrwalenia inflacji na podwyższonym poziomie, czyli wystąpienia tzw. efektów drugiej rundy" ${ }^{29}$. Wzrost oprocentowania NBP wyprzedzał zmiany w produkcji w Polsce. Proces wzrostu stóp nie trwał jednak długo. Już w marcu 2005 r. Narodowy Bank Polski zapoczątkował łagodzenie polityki monetarnej. Miało to swoje odbicie w krótko trwającej spadkowej fazie cyklu koniunkturalnego.

W badanych latach kolejny cykl podwyżek swoich stóp procentowych NBP rozpoczął w kwietniu $2007 \mathrm{r}$. Inaczej niż w $2004 \mathrm{r}$. powodem tego nie była bieżąca inflacja, gdyż kształtowała się ona na poziomie celu finalnego. Wówczas coraz większą rolę w decyzjach Rady Polityki Pieniężnej zaczęła odgrywać inflacja bazowa.

Rosnące tempo wskaźników inflacji bazowej, które spowodowane było narastającym tempem czynników popytowych, sprawiło, że bank centralny podjął decyzję o wyprzedzającej podwyżce oprocentowania swoich operacji (wykres 4). „Uwzględniając wyniki kwietniowej projekcji inflacji, Rada oceniła, że w drugiej połowie $2007 \mathrm{r}$. inflacja powinna przejściowo obniżyć się do poziomu wyraźnie niższego od celu inflacyjnego (2,5\%). Natomiast w średnim okresie, zdaniem Rady, pogorszył się bilans czynników kształtujących przyszłą inflację i prawdopodobieństwo ukształtowania się inflacji powyżej celu stało się wyższe niż prawdopodobieństwo, że będzie ona niższa od celu. W związku z tym Rada postanowiła podwyższyć stopy procentowe NBP o 0,25 punktu procentowego" ${ }^{30}$. Tak samo jak w poprzedniej fazie spadkowej, także w 2007 r. wzrost stóp NBP

${ }^{27}$ Por. W. Przychodzeń, Wahania cykliczne dynamiki PKB w Polsce w latach 1989-2009, „Ekonomista” 2011, nr 2; M. Gradzewicz et al., Cykl koniunkturalny w Polsce - wnioski z analizy spektralnej, „Bank i Kredyt” 2010, nr 41 (5); T. Fic, Cykl koniunkturalny w Polsce. Wnioski z modeli Markowa, „Ekonomista” 2009, nr 1.

${ }^{28}$ Strategia polityki pieniężnej po 2003 r., NBP, Warszawa 2003, s. 12.

${ }^{29}$ Sprawozdanie z wykonania zatożeń polityki pieniężnej $w 2004$ r., NBP, Warszawa 2005, s. 6-7.

${ }^{30}$ Sprawozdanie z wykonania zatożeń polityki pieniężnej w 2007 r., NBP, Warszawa 2008, s. 12-13. 


\section{Wykres 4}

Stopa referencyjna NBP oraz roczne stopy inflacji w Polsce

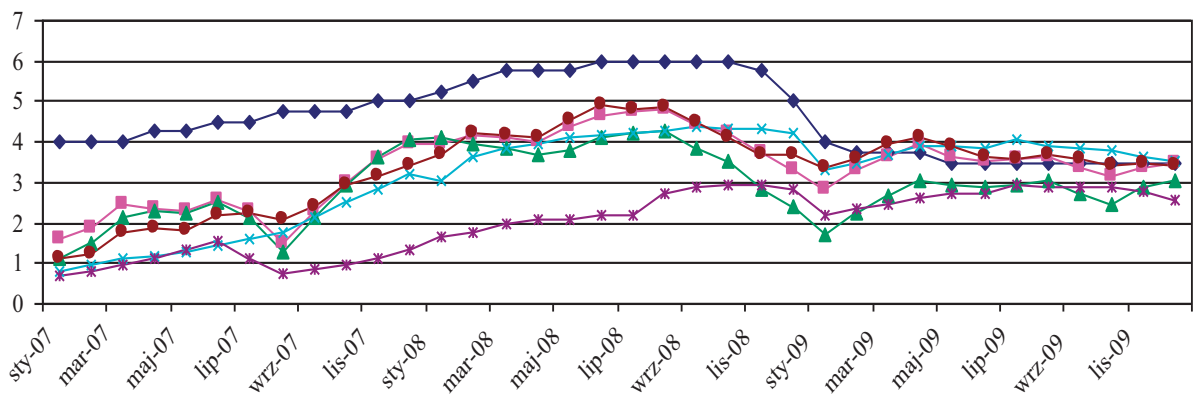

\begin{tabular}{ll}
$\longrightarrow$ stopa referencyjna & - CPI \\
$\longrightarrow$ po wyłączeniu cen administrowanych & - po wyłączeniu cen najbardziej zmiennych \\
$\rightarrow$ po wyłączeniu cen żywności i energii & $-15 \%$ średnia obcięta \\
\hline
\end{tabular}

Źródło: www.npb.pl oraz obliczenia własne.

wyprzedził osłabienie PKB, produkcji przemysłu i innych wielkości w realnej sferze polskiej gospodarki. Proces zacieśniania polityki trwał jednak zdecydowanie dłużej - aż do listopada 2008 r.

\section{KRÓTSZE PROCESY PRODUKCJI}

Źródła kryzysu gospodarczego tkwią w momencie rozpoczęcia łagodzenia polityki pieniężnej przez bank centralny ${ }^{31}$. Zanim jednak do niego dojdzie, w gospodarce występuje faza wzrostowa. Współcześnie fazę spadkową zapoczątkowuje także bank centralny, podnosząc swoje stopy procentowe w trosce o niską inflację. Skutki dla produkcji będą odwrotne niż w okresie obniżonych stóp procentowych. Nastąpi proces skracania czasu wytwarzania dóbr niższego rzędu. Przedsiębiorstwa będą eliminowały część etapów produkcji, które zostały wcześniej stworzone. Przede wszystkim będzie dotyczyło to inwestycji w branżach najbardziej oddalonych od konsumenta. Kiedyś uruchomione przedsięwzięcia - teraz stają się ekonomicznie nieopłacalne. Dlatego przy wyższej stopie procentowej nie moga być zrealizowane. Wynika to $\mathrm{z}$ austriackiej teorii kapitału ${ }^{32}$.

Proces skracania produkcji dóbr konsumpcyjnych, tak jak jej wydłużania, jest przede wszystkim zjawiskiem technicznym, który ma skutek ekonomiczny. Dlatego jest albo niemożliwy do uchwycenia przez informację statystyczną dotycząca całej gospodarki, albo ta informacja jest bardzo ogólna, tym samym bardzo niedoskonała. W tym opracowaniu, tak samo jak w opracowaniu

31 J. H. Tempelman, op. cit.

${ }^{32}$ Zob. E. von Böhm-Bawerk, The Positive Theory of Capital, London 1891. 
dotyczącym fazy wzrostowej, zastosowane zostaną wskaźniki, które moga świadczyć o skracaniu się struktury produkcji w Polsce. Będą one dotyczyć: zużycia pośredniego, wartości dodanej brutto i produkcji globalnej, nakładów przedsiębiorstw na innowacje, rozpoczętych budów mieszkań i wydanych pozwoleń na ich budowę oraz zmiany zapasów ${ }^{33}$.

\section{Wykres 5}

Roczne zmiany zużycia pośredniego, wartości dodanej brutto i produkcji globalnej (\%)

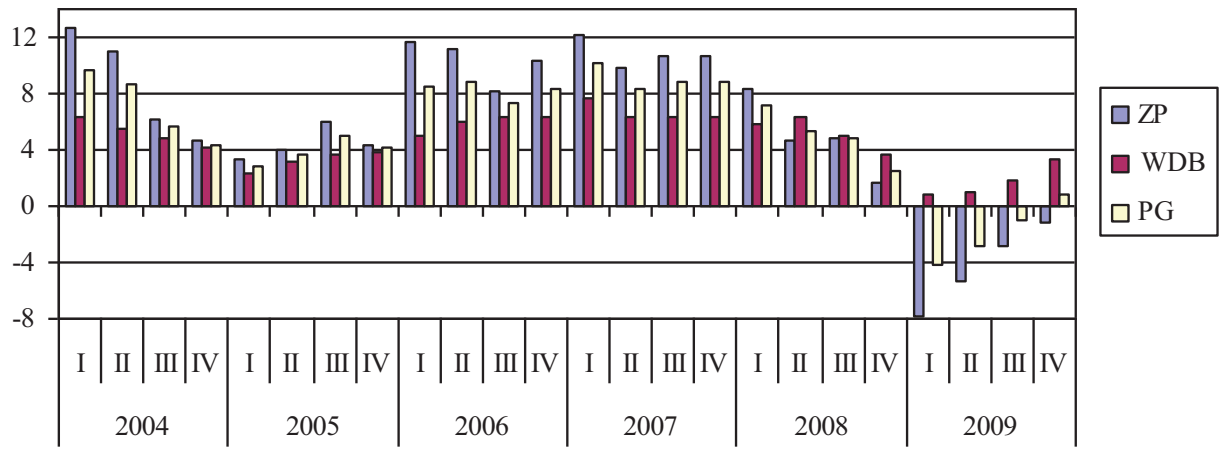

Źródło: Biuletyn Statystyczny z lat 2005-2010, GUS, Warszawa oraz obliczenia własne.

Wykorzystanie zużycia pośredniego, wartości dodanej brutto oraz produkcji globalnej $\mathrm{w}$ poszukiwaniu skracania się produkcji $\mathrm{w}$ okresie spowolnienia wzrostu PKB w Polsce może budzić zastrzeżenia, gdyż bezpośrednio nie informuje o likwidacji etapów produkcji. Jednak dedukcyjna analiza pozwala twierdzić, że część czynności przy wytwarzaniu dóbr konsumpcyjnych, która wcześniej została wprowadzona, teraz zostanie zlikwidowana całkowicie. W tym względzie szczególnie istotne są dane dotyczące zużycia pośredniego, gdyż tam występuja eliminowane w okresie spadkowym etapy produkcji. Dane zawiera wykres 5. Analiza pokazuje, że dopiero w drugiej fazie spadkowej, która była reakcja na cały okres wzrostowy 2002-2008, zużycie pośrednie w polskiej gospodarce spadło w ujęciu rocznym. Najmocniej w pierwszym kwartale $2009 \mathrm{r}$. (o 7,8\%). W okresie spadkowym lat 2004-2005 wystąpił tylko spadek tempa wzrostu zużycia pośredniego. Natomiast dynamika WDB w całym badanym okresie była dodatnia.

Interesujące zmiany udziału zużycia pośredniego i wartości dodanej w produkcji globalnej przedstawia wykres 6 . Zmiany udziałów zależą od bezpośrednich zmian kategorii, a także od ich tempa. Pierwsza faza spadkowa była krótka i płytka - nawet nie spadła relacja ZP/PG, zmniejszyło się tylko tempo jej przyrostu. Dłuższa i o wiele głębsza była druga faz spadkowa. Relacja

${ }^{33}$ A. Jędruchniewicz, op. cit. 
ZP/PG spadła II kwartale 2008 r. i spadała do końca 2009 r. Takie zachowanie badanych kategorii w polskiej gospodarce pozwala ze zrozumieniem odnieść się do tezy austriackiej teorii cyklu koniunkturalnego o skracaniu się struktury produkcji po okresie boomu. Wniosek ten dotyczy fazy spadkowej w latach 2008-2009.

\section{Wykres 6}

Roczne zmiany udziału zużycia pośredniego i wartości dodanej brutto w produkcji globalnej (\%)

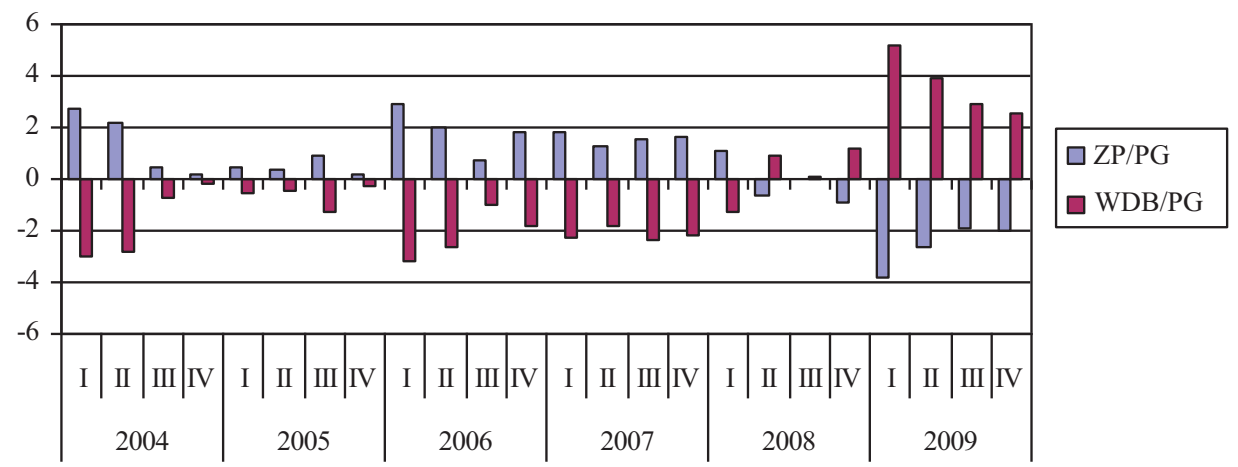

Źródło: Biuletyn Statystyczny z lat 2005-2011, GUS, Warszawa oraz obliczenia własne.

Obniżona przez bank centralny stopa procentowa prowadzi do wydłużania czasu produkcji. Według szkoły austriackiej jednym z głównych procesów, które wówczas zachodza, jest postęp techniczny. Przedsiębiorstwa zwiększają nakłady na innowacje, aby tworzyć bardziej wydajne dobra kapitałowe oraz nowocześniejsze i trwalsze dobra konsumpcyjne. Odwrotne procesy występuja po podwyżce stóp procentowych. Dochodzi wówczas do zmniejszenia inwestycji w badania i rozwój oraz opracowywanie i wdrażanie nowych technologii. Struktura produkcji skraca się. Potwierdzaja to dane z wykresu 7. W Polsce przedsiębiorstwa redukowały nakłady na innowacje w obu analizowanych spadkowych fazach cyklu.

$\mathrm{Z}$ analizy struktury nakładów na innowacje polskich przedsiębiorstw wynika, że zdecydowanie dominują inwestycje w środki trwałe (tabela 1). W latach 2003-2009 średniorocznie stanowiły 83,9\% całości. Obejmuja one inwestycje w budynki i grunty oraz maszyny i urządzenia. W fazach spowolnienia zachowywały się prawie tak samo jak nakłady ogółem. W strukturze nakładów na innowacje drugie miejsce zajmuja nakłady na badania i rozwój. Średnio w analizowanych latach obejmowały $9,3 \%$ wszystkich wydatków na innowacje. Inaczej niż nakłady ogółem wzrosły środki na B+R w 2009 r., czyli okresie dekoniunktury. Skutkowało to również wzrostem ich udziału w całości wydatków. 


\section{Wykres 7}

Nakłady na działalność innowacyjną przedsiębiorstw w mln zł (ceny stałe)

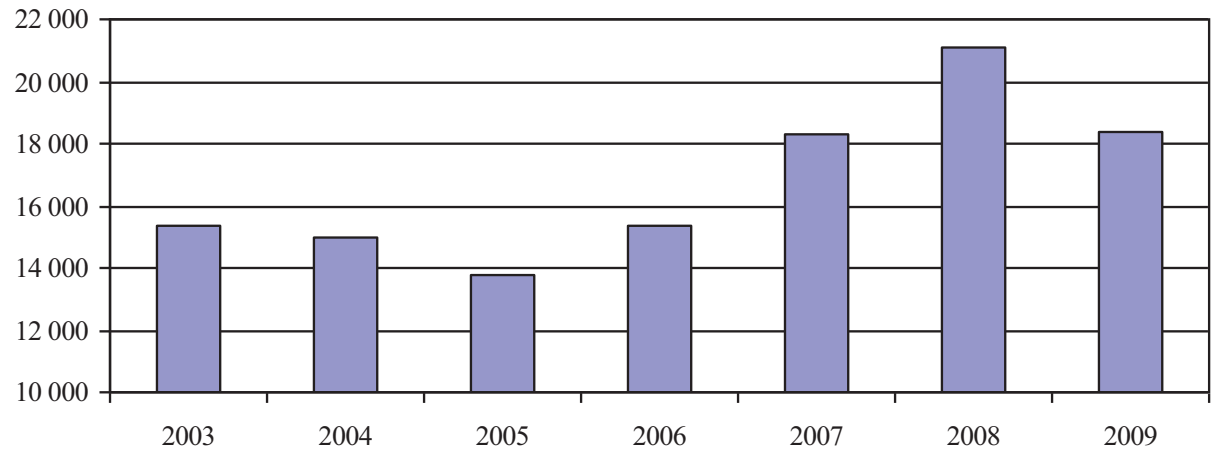

Źródło: Nauka i technika z lat 2004-2009, GUS, Warszawa 2005-2011 oraz obliczenia własne.

Tabela 1

Struktura nakładów przedsiębiorstw na innowacje (\%)

\begin{tabular}{|c|c|c|c|c|c|}
\hline Lata & $\mathbf{B}+\mathbf{R}$ & $\begin{array}{c}\text { Zakup wiedzy } \\
\text { i oprogra- } \\
\text { mowania }\end{array}$ & $\begin{array}{c}\text { Nakłady } \\
\text { inwestycyjne } \\
\text { na środki } \\
\text { trwałe }\end{array}$ & $\begin{array}{c}\text { Szkolenie } \\
\text { personelu } \\
\text { zwiazane } \\
\text { z działalnościa } \\
\text { innowacyjna }\end{array}$ & $\begin{array}{c}\text { Marketing } \\
\text { dotyczacy } \\
\text { nowych } \\
\text { i istotnie } \\
\text { ulepszonych } \\
\text { produktów }\end{array}$ \\
\hline 2003 & 11,9 & $\cdot$ & 84,9 & 0,2 & 1,5 \\
\hline 2004 & 7,9 & $\cdot$ & 87,5 & 0,3 & 2,8 \\
\hline 2005 & 9,5 & 4,3 & 82,3 & 0,3 & 2,0 \\
\hline 2006 & 9,2 & 5,0 & 81,1 & 0,3 & 2,9 \\
\hline 2007 & 8,1 & 3,4 & 83,7 & 0,3 & 2,9 \\
\hline 2008 & 8,1 & 2,6 & 84,4 & 0,8 & 2,4 \\
\hline 2009 & 10,1 & 2,9 & 83,6 & 0,2 & 1,6 \\
\hline
\end{tabular}

Źródło: Nauka i technika z lat 2003-2009, GUS, Warszawa 2004-2011.

Dla analizy zmian produkcji w cyklu koniunkturalnym ważny jest problem trwałych dóbr konsumpcyjnych. Jego rozwiązaniem jest traktowanie ich, ,jakby były inwestycjami wyższego rzędu, które produkują się i zużywają dłużej” ${ }^{34}$. Takimi dobrami są na pewno mieszkania.

${ }^{34}$ M. Skousen, op. cit., s. 205. 


\section{Wykres 8}

Roczne zmiany liczby mieszkań, których budowę rozpoczęto, oraz pozwoleń na budowę (\%)

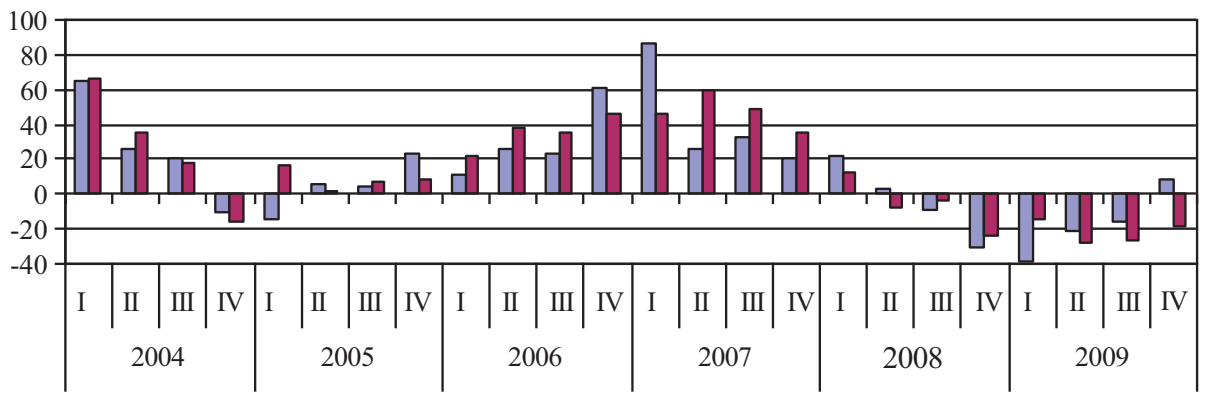

$\square$ Mieszkania, których budowę rozpoczęto $\quad \square$ Pozwolenia na budowę

Źródło: obliczenia własne na podstawie danych z www.stat.gov.pl.

Na wykresie 8 widać wyraźnie, że w Polsce w obu fazach spadkowych cyklu liczba rozpoczętych budów mieszkań oraz wydanych pozwoleń na budowę zmniejszały się. Szczególnie w latach 2008-2009. Świadczy to o skracaniu produkcji w tych okresach.

\section{Wykres 9}

Roczne zmiany zapasów produktów (\%)

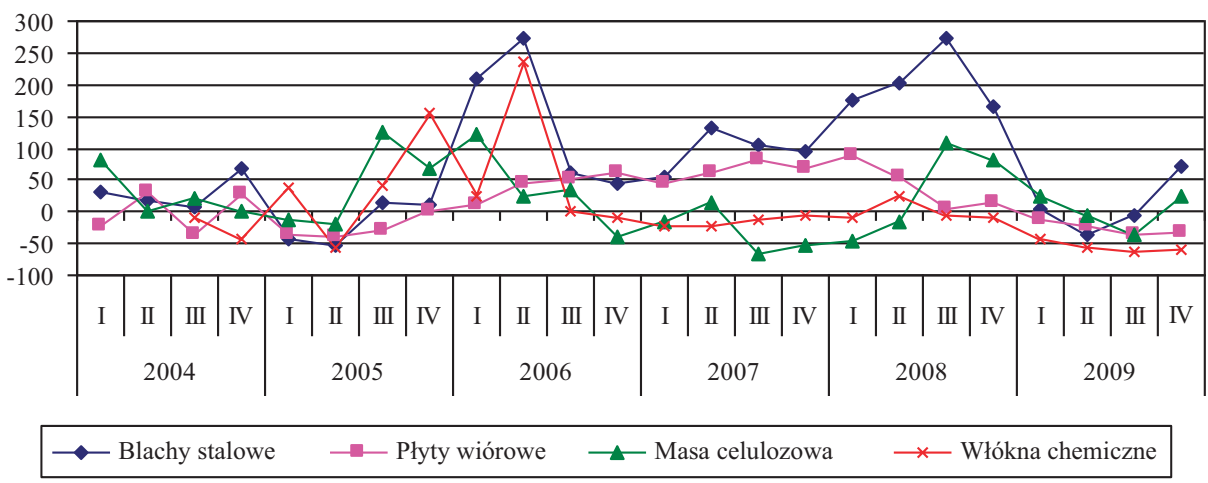

Źródło: Biuletyn Statystyczny z lat 2003-2011, GUS, Warszawa oraz obliczenia własne.

Wskaźnikiem, który również może świadczyć o zmianie czasowej struktury produkcji, jest zmiana zapasów ${ }^{35}$. Wzrost zapasów półproduktów w okresie prosperity oznacza wydłużenie wytwarzania. Analogicznie po osłabieniu eks-

35 J. Huerta de Soto, op. cit., s. 224-225. 
pansji kredytowej systemu bankowego zapasy maleja, co oznacza skracanie czasu produkcji dóbr konsumpcyjnych.

Wykres 9 zawiera zmiany zapasów czterech rodzajów wyrobów, które służą jako półprodukty w procesie wytwarzania dóbr konsumpcyjnych. W pierwszej spadkowej fazie cyklu w Polsce tempo analizowanych dóbr pośrednich było ujemne w dwóch spośród trzech kwartałów. Również w drugiej fazie spadkowej zapasy wszystkich półproduktów spadały w kilku kwartałach głównie $2009 \mathrm{r}$. Analiza zmian zapasów wskazuje, że częściowo rozmijały się one z założeniami teorii austriackiej. Zapasy masy celulozowej oraz włókien chemicznych spadały również w okresie wzrostowym. Pewnym wytłumaczeniem zmian dotyczących włókien chemicznych jest większy spadek w fazie zastoju niż prosperity. Dla kształtowania się zapasów konkretnych półproduktów ważne są też inne niż tylko stopa procentowa czynniki.

\section{PRODUKCJA BRANŻ WEDEUG STOPNIA ODDALENIA OD KONSUMENTA}

„A jednak ani ekspansja, ani kontrakcja w gospodarce nie sa uniwersalne, o czym często się zapomina" ${ }^{36}$. Jednym z głównych następstw pojawienia się nowego pieniądza fiducjarnego jest tak zwane poszerzanie struktury produkcji. Nie szuka się tutaj nowych etapów wytworzenia, ale analizuje zmiany produkcji w branżach już istniejących. Odwrotny proces, czyli zwężanie struktury produkcji, będzie zachodził w okresie dekoniunktury. Oznacza to, że w spadkowej fazie cyklu koniunkturalnego dynamika spadku wytwarzania wielu dóbr różni się znacznie. Niejednolite tempa produkcji poszczególnych branż zależą od stopnia oddalenia danych dóbr pośrednich od konsumenta oraz od trwałości dóbr konsumpcyjnych. Takie zdezagregowane podejście, oparte na sektorach gospodarki, jest charakterystycznym dla szkoły austriackiej spojrzeniem na wahania cykliczne. Według niej kategorie globalne uniemożliwiają dostrzeżenie różnorodnego obrazu cyklu, a więc różnych zmian produkcyjnych występujących w poszczególnych branżach gospodarki.

$\mathrm{Na}$ początku, tak jak w opracowaniu dotyczącym wzrostowej fazy cyklu, badaniu poddane zostaną zmiany czterech kategorii polskiej gospodarki, które reprezentuja zagregowana czasowa strukturę produkcji. Charakteryzuja się one różnym stopniem oddalenia od konsumenta. Zaczynając od najwcześniejszych etapów, są to: 1) amortyzacja brutto, 2) produkcja sprzedana przemysłu, 3) produkt krajowy brutto oraz 4) spożycie indywidualne ${ }^{37}$.

W analizowanych latach 2002-2010 wystąpiły dwie spadkowe fazy cyklu koniunkturalnego w Polsce. Jednak tutaj badaniu zostaną poddane zmiany tylko $\mathrm{w}$ drugiej fazie. Wynika to $\mathrm{z}$ uwzględnienia teraz akumulacji brutto zamiast nakładów brutto na środki trwałe. Jest to spowodowane dostępnościa danych o akumulacji w całej gospodarce. Takie ujęcie jest szersze, a więc lepiej opisuje zagadnienie. Ponadto lata 2002-2008 można potraktować jako jedną

${ }^{36}$ M. Skousen, op. cit., s. 341.

${ }^{37}$ A. Jędruchniewicz, op. cit. 


\section{Wykres 10}

Roczne zmiany akumulacji, produkcji przemysłowej, PKB i spożycia w Polsce (\%)

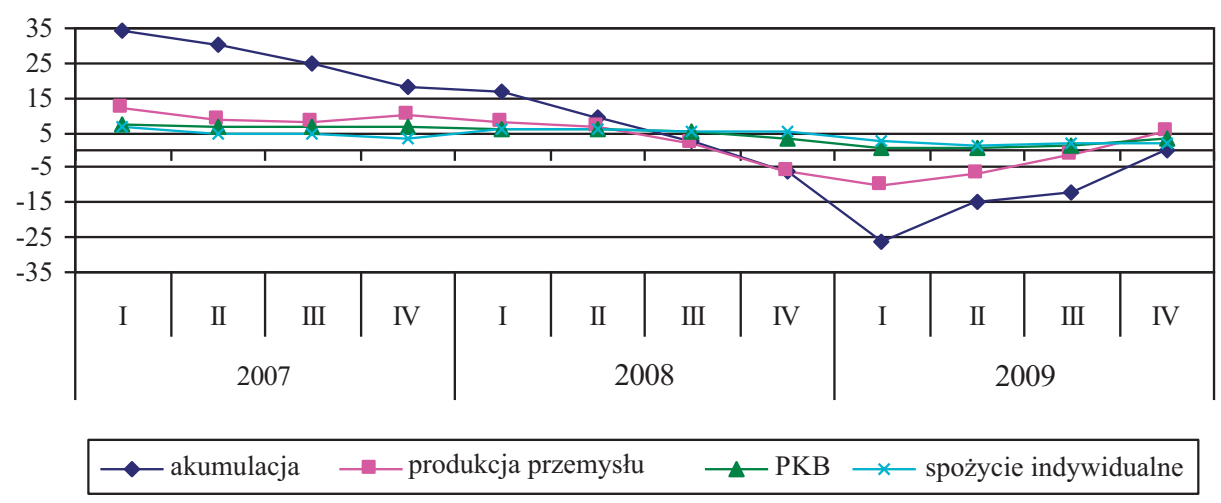

Źródło: obliczenia własne na podstawie Biuletynu Statystycznego z lat 2008-2010, GUS, Warszawa 2008-2010.

wielką fazę wzrostową. Wykres 10 obrazuje kształtowanie się analizowanych kategorii. W okresie dekoniunktury największymi zmianami charakteryzowała się akumulacja. Jej średni roczny spadek wyniósł 11,3\%. Cechowała się także największym odchyleniem standardowym, które wyniosło 10,7 punktu procentowego. Roczne zmiany wahały od $+2,9$ do $-26,0 \%$. Duże zmiany dotyczyły też produkcji sprzedanej przemysłu. Charakteryzowała się ona średniorocznym spadkiem 4,4\% oraz odchyleniem standardowym 4,8 punktu procentowego. Natomiast niewielka zmienność dotyczyła PKB i spożycia indywidualnego. Przeciętnie najbardziej wzrastała konsumpcja o 3,5\%. Zmienność obu kategorii była identyczna.

\section{Wykres 11}

Zmiany akumulacji, produkcji przemysłowej, PKB i spożycia w fazie spadkowej lat 2008-2009 (\%)

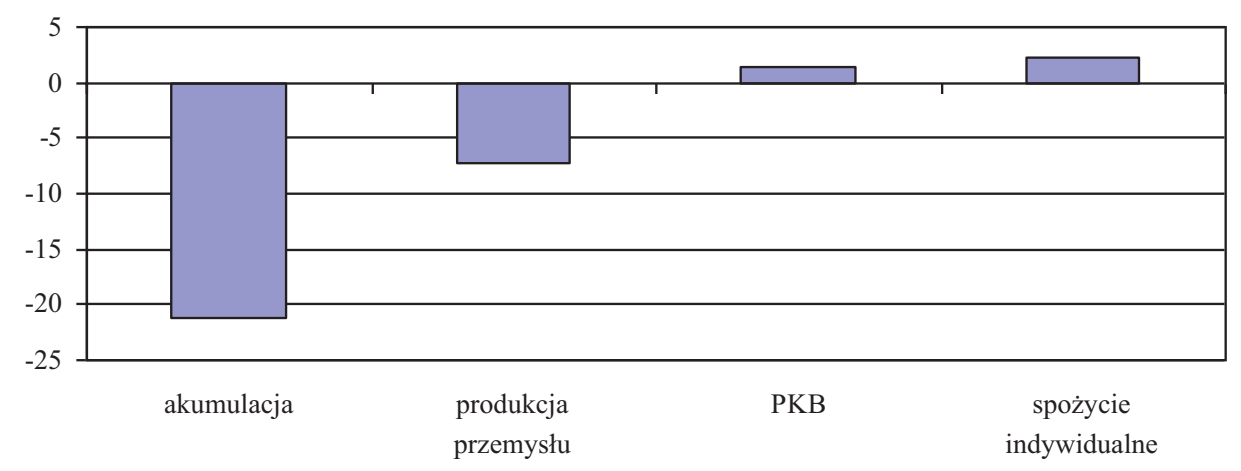

Źródło: obliczenia własne na podstawie Biuletynu Statystycznego z lat 2008-2009, GUS, Warszawa 2008-2010 oraz www.stat.gov.pl. 
Zmiany, które zaszły od początku III kwartału 2008 do końca III kwartału 2009 r. potwierdzaja podstawowa, weryfikowaną w tym opracowaniu, tezę austriackiej teorii cyklu koniunkturalnego. Wartości liczone w cenach stałych analizowanych kategorii zmieniły się następująco: akumulacja brutto spadła o 21,2\%, produkcja sprzedana przemysłu spadła o 7,2\%; produkt krajowy brutto wzrósł o 1,4\%; a spożycie indywidualne wzrosło o $2,2 \%$ (wykres 11). Zgodnie $\mathrm{z}$ teorią austriacką dynamika produkcji zależy od jej odległości od konsumpcji. W Polsce największy spadek odnotowała kategoria najbardziej odległa od konsumenta. Natomiast wzrosła konsumpcja. Przyczyną tego był silny wzrost podaży pieniądza.

\section{Wykres 12}

Roczne zmiany produkcji dóbr inwestycyjnych, zaopatrzeniowych i konsumpcyjnych (\%)

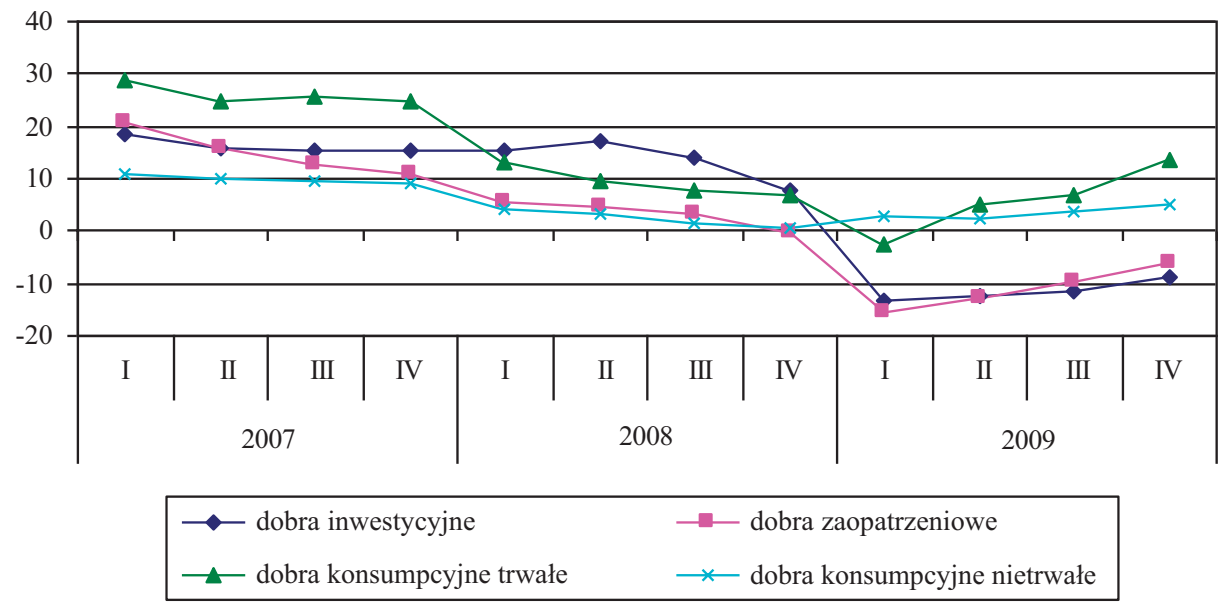

Źródło: obliczenia własne na podstawie Biuletynu Statystycznego z lat 2007-2010, GUS, Warszawa 2007-2010.

W kolejnym badaniu zmiany analizowanych kategorii w fazach spadkowych również będą, ze względu na dostępność danych, dotyczyć lat 2008-2009. Wykres 12 przedstawia kształtowanie się dynamiki dóbr inwestycyjnych. Najdalej od konsumenta znajduja się dobra inwestycyjne. Ich roczna produkcja spadała średnio o $3,1 \%$, odchylenie standardowe zaś wyniosło 12,9 punktu procentowego. Świadczy to o dużej zmienności produkcji tych dóbr. Największy wzrost wystapił w III kwartał 2008 r. (14\%), a największy spadek - w I kwartale 2009 r. (-13,1\%). Bliżej konsumenta występuja dobra zaopatrzeniowe. Średniorocznie spadały o 7\%, a ich zmienność wyniosła 8,2 punktu procentowego. Przeciętnie najmniej wzrastała produkcja dóbr konsumpcyjnych nietrwałych $-2,4 \%$. Miały one również najmniejszą zmienność - 1,3 punktu procentowego. Zaskoczeniem są natomiast zmiany produkcji trwałych dóbr konsumpcyjnych. Średniorocznie rosły o $4,8 \%$. Według podejścia austriackiego powinny zachowywać się jak dobra znacznie oddalone od konsumpcji. Jednak konsumenci w Polsce potraktowali okres dekoniunktury jako okazję do nabycia tych dóbr po niższych cenach. 


\section{Wykres 13}

Roczne zmiany produkcji wyrobów (\%)

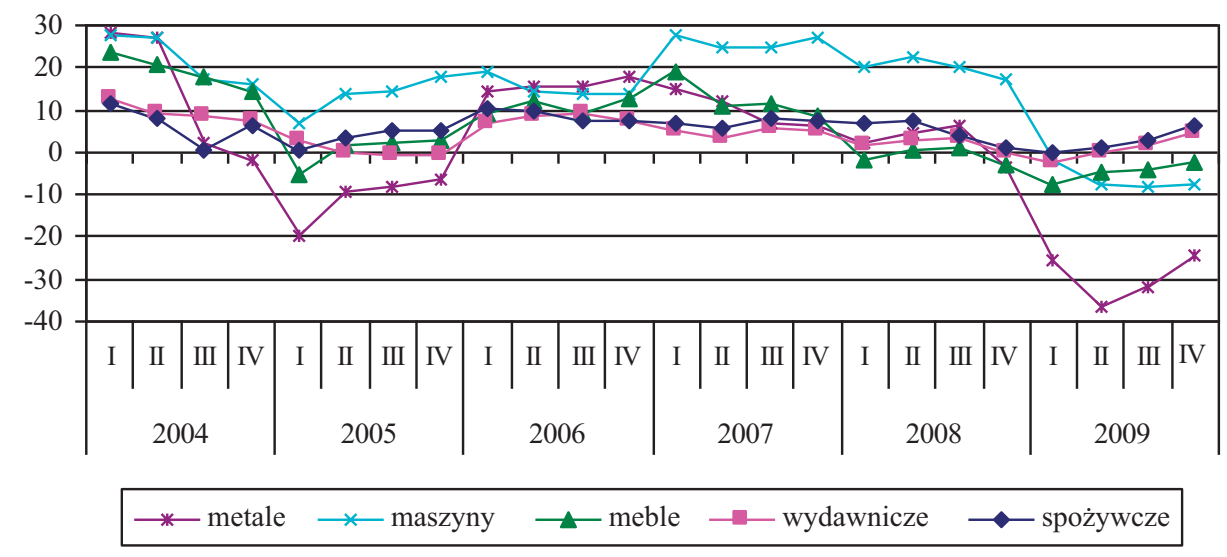

Źródło: obliczenia własne na podstawie Biuletynu Statystycznego z lat 2004-2010, GUS, Warszawa 2004-2010 oraz www.stat.gov.pl.

Analizowana wyżej produkcja przemysłowa, traktowana jako całość, została podzielona na branże. Zgodnie z podstawowym postulatem teorii austriackiej wyszczególnione branże różnią się stopniem oddalenia od konsumenta. W pierwszej całej fazie spadkowej zmniejszyła się tylko produkcja metali (wykres 13). Zmiany w tych sektorach potwierdzają, że ta faza cyklu była bardzo płytka. Natomiast znaczące zmiany produkcji zaszyły w drugiej fazie spadkowej. W ciągu pięciu kwartałów największy spadek (o 47,6\%) zanotowała branża metalowa. Jej roczna produkcja spadała średnio o 18,3\%. Duża była też zmienność produkcji tego sektora. Odchylenie standardowe wyniosło aż 18,5 punktu procentowego. Największy spadek wystapił w II kwartale $2009 \mathrm{r}$. $(-36,8 \%)$, jedyny zaś wzrost - w III kwartale 2008 r. (6\%). Natomiast w analizowanym okresie produkcja artykułów spożywczych wzrosła najsilniej - o 1,5\%. Była ona też najbardziej stabilna. Odchylenie standardowe wyniosło 1,6 punktu procentowego. Dane z wykresu 13 potwierdzaja, że zachowanie się produkcji w polskiej gospodarce, szczególnie w drugiej fazie spadkowej, jest zgodne $\mathrm{z}$ austriacka teorią cyklu koniunkturalnego. Tempo względnych spadków w branżach było proporcjonalne do stopnia oddalenia od konsumenta tych branż.

Ostatnimi etapami w czasowej strukturze wytwarzania i dostarczania konsumentowi towarów są etapy sprzedaży hurtowej i detalicznej. Tutaj także zmiany powinny ułożyć się we wzór przedstawiony przez Austriaków. Sprzedaż hurtowa powinna być bardziej wrażliwa na politykę banku centralnego niż sprzedaż detaliczna, gdyż jest dalej od ostatecznego odbiorcy. W pierwszym fazie spadkowej zmiany obu badanych kategorii były podobne (wykres 14). Jednak bardziej zmianą wielkością była sprzedaż hurtowa. Wyraźniejsze zmiany zaszły $\mathrm{w}$ fazie spadkowej lat 2008-2009. W ciągu pięciu kwartałów handel hurtowy spadł (o 9,6\%), a detaliczny wzrósł (o 0,5\%). Średniorocznie 


\section{Wykres 14}

Roczne zmiany sprzedaży hurtowej i detalicznej (\%)

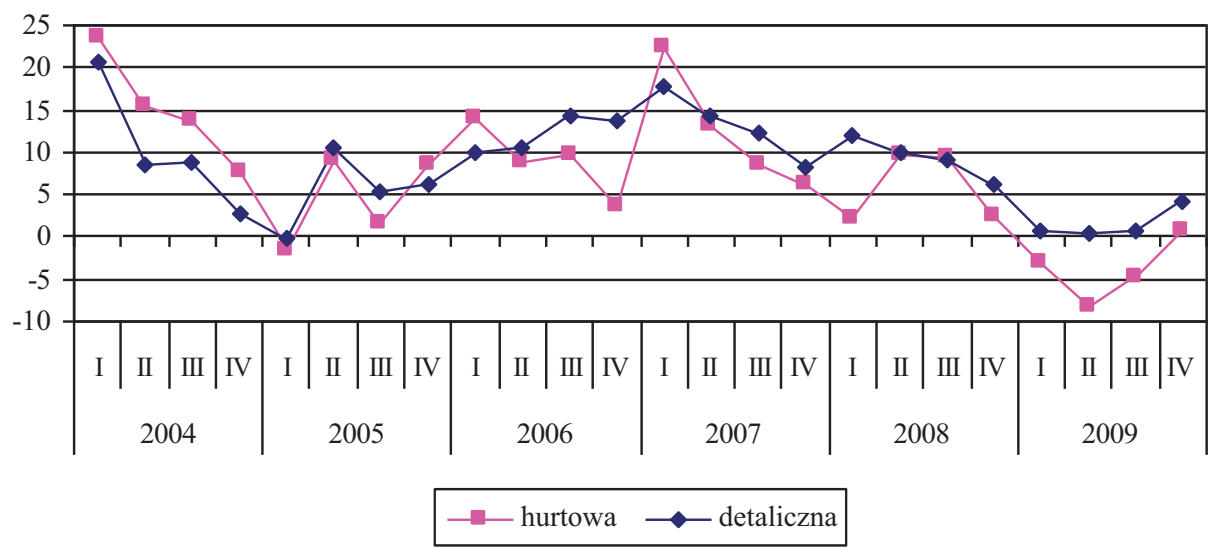

Źródło: obliczenia własne na podstawie Biuletynu Statystycznego z lat 2004-2010, GUS, Warszawa 2004-2010.

sprzedaż hurtowa zmniejszała się o 0,9\%, a detaliczna wzrastała o 3,4\%. Także zmienność różniła obie sprzedaże. Odchylenie standardowe handlu hurtowego wyniosło 7 punktów procentowych, zaś detalicznego - 3 punkty procentowe. Analizowane zmiany także potwierdzaja tezy szkoły austriackiej. W Polsce w okresie dekoniunktury wystąpił zarówno względny, jak i bezwzględny spadek sprzedaży hurtowej.

\section{ZAKOŃCZENIE}

Według austriackiej teorii cyklu koniunkturalnego okres dekoniunktury jest odłożoną w czasie, ale nieuniknioną konsekwencją ekspansywnej polityki banku centralnego. Bezpośrednio fazę spadkową zapoczątkowuje działanie kilku czynników: wzrost cen dóbr konsumpcyjnych, wzrost zysków księgowych firm produkujących najbliżej konsumenta, wzrost stóp procentowych, pojawienie się strat księgowych firm produkujących na początkowych etapach oraz spadek płac realnych. W klasycznym ujęciu ostatnią częścią spadkowej fazy cyklu jest depresja. Jest to okres stabilizowania się na niskich poziomach wielu kategorii. Odgrywa ona pozytywną rolę w procesie rozwoju gospodarczego. Ma za zadanie na nowo dopasować czasową strukturę produkcji do czasowej struktury konsumpcji.

Ze względu na krótki okres trwania pierwszej fazy spadkowej, a przede wszystkim na jej płytki charakter, weryfikacja postawianych we wstępie hipotez została dokonana głównie na podstawie zmian, które zaszły w drugiej fazie spadkowej. Przeprowadzona w opracowaniu analiza, oparta na przyjętych wskaźnikach, pozwala na potwierdzanie pierwszej hipotezy. O skracaniu się 
struktury produkcji w Polsce świadczą: spadek zarówno zużycia pośredniego, jak i jego relacji do produkcji globalnej, a wzrost relacji wartości dodanej brutto do produkcji globalnej; redukcja nakładów przedsiębiorstw na innowacje; zmniejszanie się rozpoczętych budów mieszkań oraz liczby wydanych pozwoleń na budowę; jak również spadek zapasów analizowanych półproduktów.

Dokonane w opracowaniu badania pozwalają także, jak w wypadku pierwszej hipotezy, pozytywnie zweryfikować hipotezę drugą. W spadkowych fazach cyklu koniunkturalnego w Polsce, szczególnie w okresie 2008-2009, struktura produkcji uległa zwężeniu. Najszybciej spadała produkcja w branżach najbardziej oddalonych od konsumenta, natomiast w sektorach bliższych - najwolniej lub wręcz wzrosła. Świadczą o tym: najmocniejszy spadek akumulacji brutto, a wzrost spożycia indywidualnego; zmniejszenie się produkcji dóbr inwestycyjnych, zwiększenie zaś nietrwałych dóbr konsumpcyjnych; największy spadek produkcji metali oraz maszyn i urządzeń; a także spadek sprzedaży hurtowej, a wzrost detalicznej oraz jej większa zmienność mierzona odchyleniem standardowym.

dr Andrzej Jędruchniewicz

Szkota Gtówna Gospodarstwa Wiejskiego w Warszawie

jedruchniewicz@o2.pl

\section{PRODUCTION IN THE DOWNWARD PHASE OF THE BUSINESS CYCLE IN POLAND}

\section{Summary}

The paper is of theoretical and empirical character. Its main objective is to verify two hypotheses that are fundamental to the Austrian business cycle theory. One claims that a restrictive monetary policy causes a shortening of the production structure. The other states that increases in interest rates lead to relative differences in the decline of the output in manufacturing industries that produce goods at different distances from the consumer.

The analysis presented in the paper was based on selected indicators and allowed to positively verify both hypotheses. Interest rate increases effected by the National Bank of Poland led to the formation of downward phases of the cycle. During the examined period we observed a decrease in the production time of final goods as well as relative differences in the declines in the output of the manufacturing industries which varied in their distance to the final recipients. 
Copyright of Journal of Law, Economics and Sociology is the property of Faculty of Law and Administration of Adam Mickiewicz University in Poznan and its content may not be copied or emailed to multiple sites or posted to a listserv without the copyright holder's express written permission. However, users may print, download, or email articles for individual use.

Właścicielem praw autorskich do „Ruchu Prawniczego, Ekonomicznego i Socjologicznego” jest Wydział Prawa i Administracji Uniwersytetu im. Adama Mickiewicza w Poznaniu. Zawartość czasopisma nie może być kopiowana, przesyłana do innych stron internetowych bądź zamieszczana na blogach bez pisemnej zgody wydawcy. Niemniej artykuły można drukować, kopiować lub przesyłać w formie elektronicznej na własny użytek. 